\title{
Quantitative Simultaneous Estimation of Water Soluble Vitamins, Riboflavin, Pyridoxine, Cyanocobalamin and Folic Acid in Neutraceutical Products by HPLC
}

\author{
Shahnaz Perveen ${ }^{*}$, ,, Arfa Yasmin ${ }^{a}$ and Khalid Mohammed Khan ${ }^{\mathrm{b}}$ \\ ${ }^{a}$ PCSIR Laboratories Complex, Karachi, Shahrah-e-Dr. Salimuzzaman Siddiqui, Karachi-75280, Pakistan \\ ${ }^{b}$ H. E. J. Research Institute of Chemistry, International Center for Chemical and Biological Sciences, University \\ of Karachi, Karachi-75270, Pakistan
}

\begin{abstract}
Water soluble vitamins e.g. riboflavin $\left(\mathrm{B}_{2}\right)$, pyridoxine $\left(\mathrm{B}_{6}\right)$, cyanocobalamin $\left(\mathrm{B}_{12}\right)$ and folic acid in neutraceutical product have been determined simultaneously by using a rapid, precise and time saving new high performance liquid chromatographic method and its validation. The method involves gradient elution of mobile phase through $\mathrm{C}_{18}$ discovery column (Supelco, Sigma-Aldrich) in a reverse phase chromatography with UV detection at $254 \mathrm{~nm}$ at ambient temperature. The ranges for quantification for $\mathrm{B}_{2}, \mathrm{~B}_{6}, \mathrm{~B}_{12}$ and folic acid were $0.13 \mathrm{mg} \mathrm{g}^{-1}\left(0.57-131 \mu \mathrm{g} \mathrm{g}^{-1}\right), 0.235 \mathrm{mg} \mathrm{g}^{-1}(3-235$ $\left.\mu \mathrm{g} \mathrm{g}^{-1}\right), 7.94 \times 10^{-2} \mathrm{mg} \mathrm{g}^{-1}\left(8-80 \mu \mathrm{g} \mathrm{g}^{-1}\right)$ and $9.66 \times 10^{-2} \mathrm{mg} \mathrm{g}^{-1}\left(10-97 \mu \mathrm{g} \mathrm{g}^{-1}\right)$, respectively. For the validation of the method, linearity, precision, accuracy and robustness have been performed. The repeatability was measured in terms of RSD value. The RSD for all vitamins was below $1 \%$. Recovery of vitamins ranges from 98.6 to $100.5 \%$.
\end{abstract}

\section{INTRODUCTION}

In 1933, Kuln and co-workers first isolated riboflavin from eggs in a pure crystalline state and named it ovoflavin. Riboflavin in free form is found in the retina of the eye, in whey and in urine. Riboflavin is distributed in some degree in virtually all naturally occurring foods, e.g. liver, heart, kidney, milk, eggs, lean meats and fresh leafy vegetables are particularly good source of riboflavin [1]. Riboflavin can be assayed by chemical, microbiological, and biological methods. Both fluorometric [2] and microbiological [3] assays are official methods of the Association of Official Analytical Chemicals (AOAC). High performance liquid chromatography (HPLC) has been applied to the determination of riboflavin in a variety of foods by reverse-phase HPLC method [4]. Its use as a column additive is approved by the Food and Drug Administration 21 CFR (73:450).

Vitamin $B_{6}$ is identified and named pyridoxine in 1934. The analysis of vitamin $B_{6}$ in food is complicated by the fact that six forms (vitamers) are found in nature, therefore microbiological, colorimetric and HPLC methods are currently used [5-7]. Rich sources of vitamin $\mathrm{B}_{6}$ are chicken, pork, fish, organ meats, and eggs.

Vitamin $\mathrm{B}_{6}$ deficiency symptonology includes the following chemical signs: eczema and seborrheic dermatosis, in the ears, nose, and mouth; cheilosis, glossitis and angular stomatitis and hypochromic and microcytic anemia.

Vitamin $\mathrm{B}_{12}$ deficiency includes paresthesias of the hands and feet, decreased deep-tendon reflexes, unsteadiness and potential psychiatric problems. Such as moodiness,

*Address correspondence to this author at the PCSIR Laboratories Complex, Karachi, Shahrah-e-Dr. Salimuzzaman Siddiqui, Karachi-75280, Pakistan; Tel: +92-21-4655557/62; Fax: +92-21-4655557;

E-mail: dr_shahnaz_perveen@yahoo.com hallucinations, delusions and psychosis. Vitamin $\mathrm{B}_{12}$ is not present in plants, and therefore dietary deficiencies can occur in strict vegetarians. Cyanocobalamin is the commercial form of vitamin $\mathrm{B}_{12}$ and specifications are found in the codex for use as food [8], and in the USP for pharmaceutical use [9].

Vitamin $\mathrm{B}_{12}$ can be determined by microbiological, radioisotope dilution, spectrophotometric, chemical or biological methods employing animals [10-12]. Spectrophotometric determination at $550 \mathrm{~nm}$ is relatively insensitive and is useful for the determination of vitamin $B_{12}$ in high potency products such as premixes. Thin layer chromatography and open column chromatography have been applied to both direct assays of cyanocobalamins. An indirect method is atomic absorption spectrophotometric analysis of cobalt in dry feeds. Recently a high performance liquid chromatographic (HPLC) method is reported which is suitable for premixes, raw materials and pharmaceutical products containing 20-100 $\mu \mathrm{g}$ vitamin $\mathrm{B}_{12}$ [13].

Folic acid deficiency is the result of megaloblastic anemia. One of the chemical signs of acute folate deficiency includes a red, painful tongue. Folic acid as pteroylglutamic acid is not found naturally in foods. Methods for determining folic acid in food include biological, microbiological, chemical, chromatographic and radiometric assays [14-17].

Analysis of water soluble vitamins $\mathrm{B}_{2}, \mathrm{~B}_{12}$, folic acid, biotin and pantothenic acid based on biosensor-based vitamin analysis technology, this method is sensitive but did not analyze the vitamin $\mathrm{B}_{6}$ simultaneously [18]. In another method simultaneous determination of seven water soluble vitamins nicotinamide, thiamin, riboflavin, pyridoxine, pyridoxal, pyridoxamine, cyanocobalamine and folic acid were carried out by using ion-pair chromatography [19]. Nevertheless, the detection time is very high and the UV detector has to set at different wavelengths. Literature showed simul- 
taneous determination of four B-group vitamins, $\mathrm{B}_{1}, \mathrm{~B}_{3}, \mathrm{~B}_{6}$ and $\mathrm{B}_{12}$ but $\mathrm{B}_{12}$ has been detected separately at $550 \mathrm{~nm}[20]$.

We want report herein a new method which simultaneously analyses four water soluble vitamins $\mathrm{B}_{6}$, folic acid, $\mathrm{B}_{12}$, and $\mathrm{B}_{2}$ in a complex mixture (neutraceutical) by HPLC using UV detector at $254 \mathrm{~nm}$. Details of the method and its validation were reported.

\section{MATERIALS AND METHODS}

Potassium dihydrogen phosphate (BDH, Anala R), formic acid (BDH, Anala R) and methanol (BDH, Anala R) were used. Standard solutions of riboflavin $\left(\mathrm{B}_{2}\right)$, pyridoxine $\left(\mathrm{B}_{6}\right)$, cyanocobalamin $\left(\mathrm{B}_{12}\right)$ and folic acid were freshly prepared. Folic acid, vitamins $B_{2}, B_{6}$ and $B_{12}$ were purchased from Sigma-Aldrich. Acetic acid (BDH, Anal R), $\mathrm{HCl}$ (reagent grade and water (deionized) was used.

\section{HPLC Method}

The high performance liquid chromatographic system used was equipped with a solvent delivery 200 HPLC pump (Perkin Elmer Series) with online degasser, UV/VIS detector (Perkin Elmer Series 200), Perkin Elmer NCI 900 network chromatography interface, and a data processing unit compaq.

HPLC column discovery $\mathrm{C}_{18}, 25 \mathrm{~cm} \times 4.6 \mathrm{~mm}, 5 \mu \mathrm{m}$ (Supelco, Sigma-Aldrich) was used for the separation of vitamins. A gradient of methanol and buffer (30:70, in eight minutes) of $50 \mathrm{mM}(0.05 \mathrm{M})$ potassium dihydrogen phosphate having $\mathrm{pH} 4.2 \pm 0.1$, adjusted with formic acid was used as mobile phase. The flow rate was maintained at $1 \mathrm{ml}$ $\mathrm{min}^{-1}$. Wave length of detection was $254 \mathrm{~nm}$. An injection volume of $20 \mu \mathrm{L}$ was chromatographed, and the whole chromatography was performed at ambient temperature.

\section{Preparation of Standard Solution}

The standard samples $\mathrm{B}_{2}, \mathrm{~B}_{6}, \mathrm{~B}_{12}$ and folic acid $100 \mathrm{mg}$ (each) were accurately weighed and transferred into three $100 \mathrm{~mL}$ volumetric flask separately and $100 \mathrm{mg}$ of $\mathrm{B}_{2}$ was transferred into $250 \mathrm{~mL}$ volumetric flask. Initially $7 \mathrm{~mL}$ of acetic acid and $50 \mathrm{~mL}$ of methanol were added to each flask; the contents were dissolved by sonication for $10 \mathrm{~min}$ and allowed to cool to ambient temperature. The contents were diluted to volume with water and thoroughly mixed. These solutions were used as reference working standard solution (Fig. 1). Prior to injecting into the liquid chromatograph, the solution was filtered through $0.45 \mu \mathrm{m}$ membrane filter. The samples were quite stable at room temperature. The stock solutions of standards were kept in a refrigerator for further use and remain unchanged for a period of a month.

\section{Preparation of Sample Solution}

$15.07 \mathrm{~g}$ of neutraceutical enriched with vitamins was accurately weighed and transferred into a $250 \mathrm{~mL}$ round bottom flask. Initially about $10 \mathrm{~mL}$ of $0.1 \mathrm{~N} \mathrm{HCl}$ and $80 \mathrm{~mL}$ water was added and then reflux on boiling water bath for 15 min. After completion of refluxing period the flask was cooled and volume made up to $100 \mathrm{~mL}$ in a volumetric flask. The content was centrifuged (1400 rpm) to remove suspended material. The supernatant solution was first filtered through a Whatman No. 1 filter paper and the resulting filtrate was again filtered through $0.45 \mu \mathrm{m}$ membrane filter before injection into LC system (Fig. 2). The stock solutions of sample were kept in a refrigerator for further use and remain unchanged for a period of a month.

\section{RESULTS AND DISCUSSIONS}

Standard solutions containing $\mathrm{B}_{2}, \mathrm{~B}_{6}, \mathrm{~B}_{12}$ and folic acid equal to 20,50 for linearity, $80,100,120,150$ and $180 \%$ were prepared and examined by the assay procedure. The peak area responses measured for $\mathrm{B}_{2}, \mathrm{~B}_{6}, \mathrm{~B}_{12}$ and folic acid were plotted versus concentration and a linear response was obtained over the range of concentrated studied for all four ingredients. The slope of calibration curve and proximity of all points to the calibration curve demonstrates that the method has adequate sensitivity to the concentrated of vitamins $\mathrm{B}_{2}, \mathrm{~B}_{6}, \mathrm{~B}_{12}$ and folic acid.

The accuracy of the assay procedure was determined by carrying out recovery experiments by spiking the standard. Amounts of $\mathrm{B}_{2}, \mathrm{~B}_{6}, \mathrm{~B}_{12}$ and folic acid equivalent to 20,50 , $80,100,120$ and $150 \%$ of the theoretical assay concentration were added to the formula amount of neutraceutical preparation and the mixtures were subjected to the assay procedure. The results so obtained are summarized in Table 1. The recovery experiment shows that the method is sufficiently accurate and there is no significant interaction between the active components and excepients.

The precision of assay method was determined under repeatability condition by an experiment in which six preparations were made from the same batch of formulation and were analyzed by one operator on a single occasion. The results are presented in Table $\mathbf{2}$. The intermediate precision was assessed by another experiment in which two analysts on two different instruments with six independent determinations assayed the same batch of formulation. The results are statistically valid as shown in Table $\mathbf{3}$.

The robustness of the assay method was assessed with respect to alternations in flow rate, column (same column but of different batch) and change in wave length of UV of the standard and sample, as stability of working standard and test solutions stored in amber glass at ambient temperature. The results show that the new HPLC method is robust to small changes in flow rate, change in column, and the solutions exhibited a good degree of stability. The LOD for $\mathrm{B}_{2}$, $\mathrm{B}_{6}, \mathrm{~B}_{12}$ and folic acid were found to $0.57,3,8$ and $10 \mu \mathrm{g} \mathrm{g}^{-1}$, respectively.

Neutraceutical preparation omitting $\mathrm{B}_{2}, \mathrm{~B}_{6}, \mathrm{~B}_{12}$ and folic acid was examined by the assay procedure. No peak due to excipients in the formulation was observed at the typical retention times for $\mathrm{B}_{2}, \mathrm{~B}_{6}, \mathrm{~B}_{12}$ and folic acid. Therefore, it is concluded that the assay method is specific for both active ingredient in the presence of excipients of formulated product. The suitability of the system was defined by determining the value of column efficiency, tailing factor and resolution factor using the method in VSP. Column efficiency was greater than 1000 per column, tailing factor was not more than 2 and resolution factor is greater than 3 for $\mathrm{B}_{2}, \mathrm{~B}_{6}, \mathrm{~B}_{12}$ and folic acid (Table 4). 


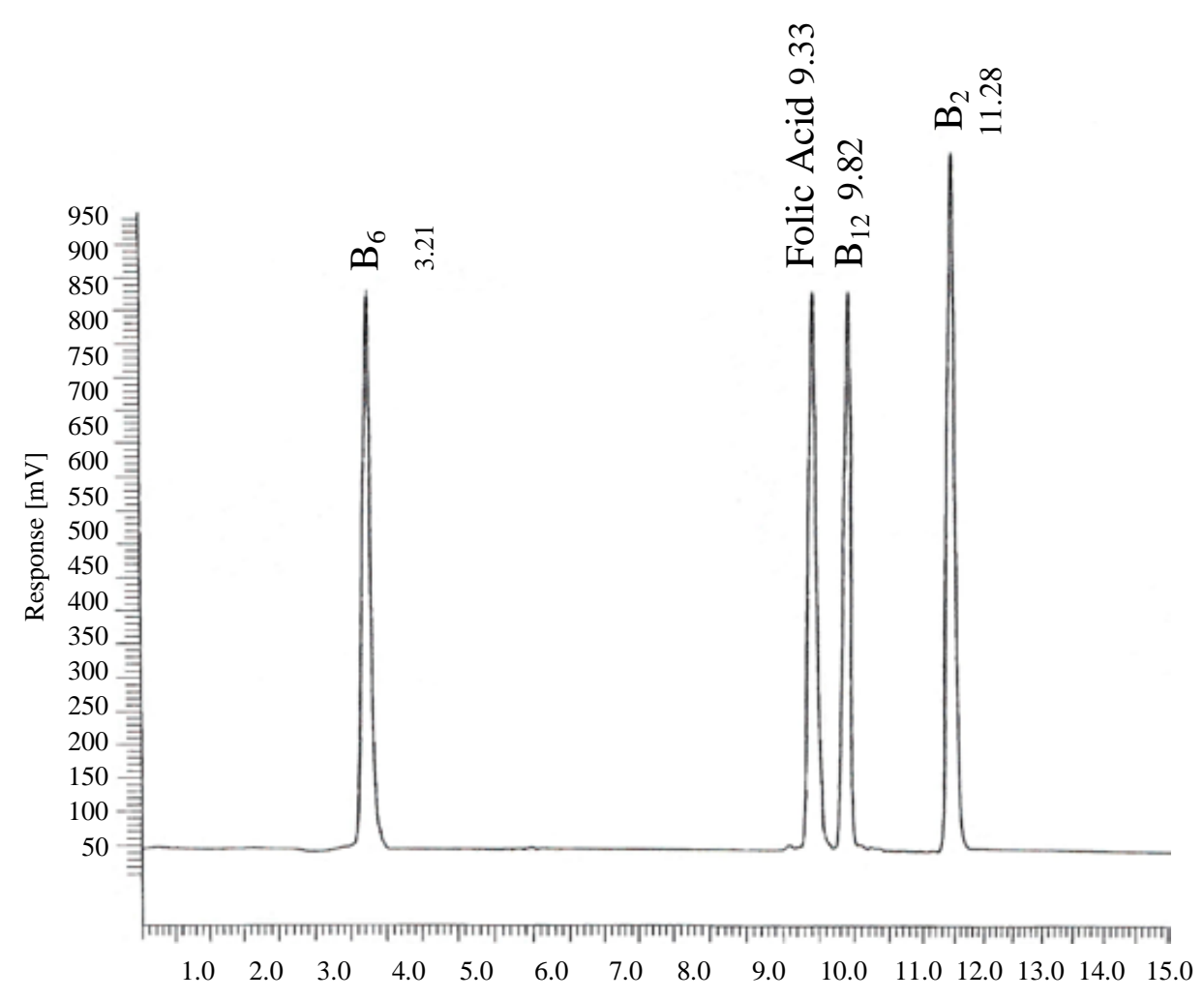

Fig. (1). Chromatogram of standards $B_{6}$, folic acid, $B_{12}$ and $B_{2}$.

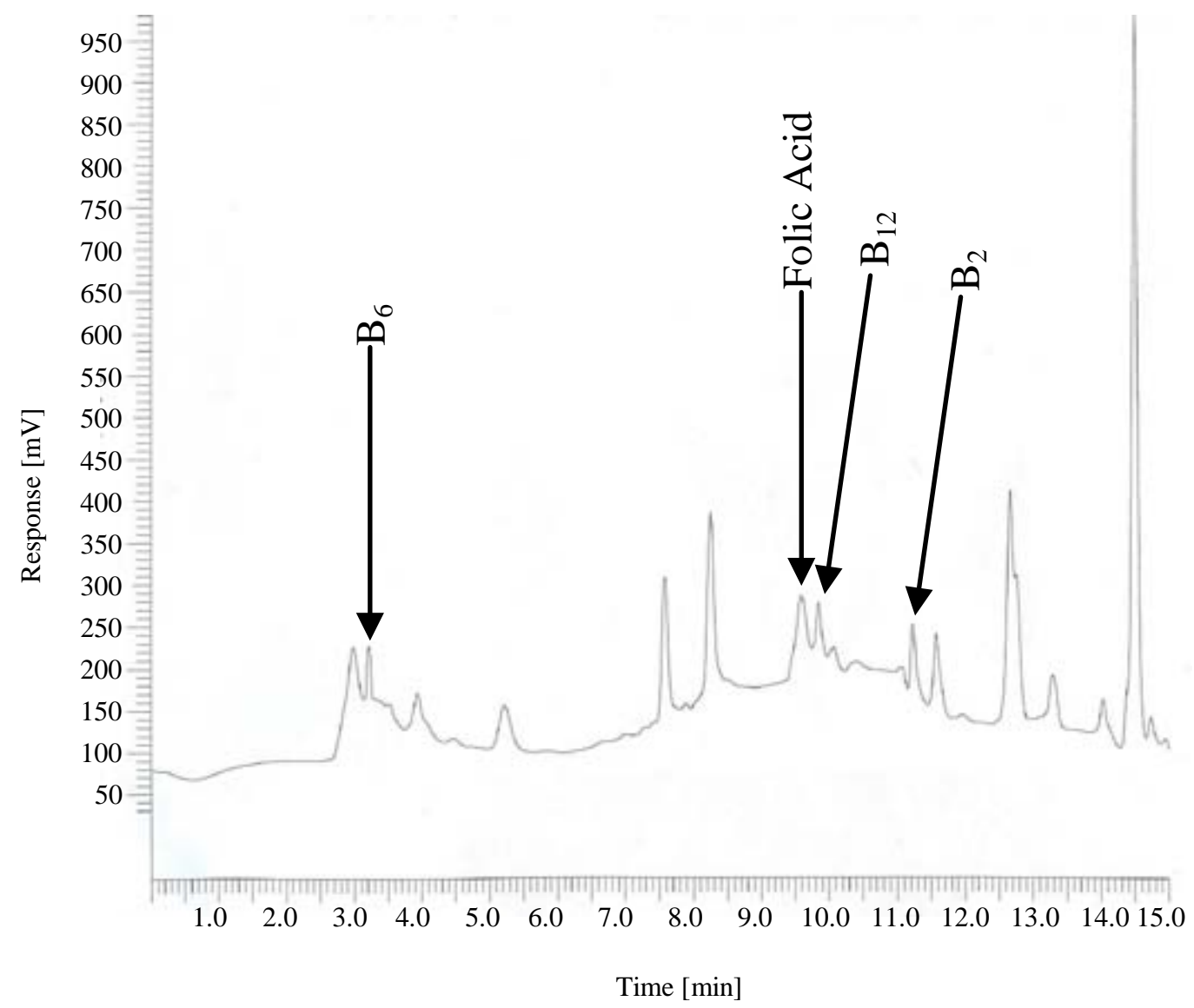

Fig. (2). Chromatogram of sample. 
Table 1. Recovery Experiment (Reproducibility) for $B_{2}, B_{6}, B_{12}$ and Folic Acid by Proposed HPLC Method $(n=6)$

\begin{tabular}{|c|c|c|c|c|c|c|c|c|c|c|c|}
\hline \multicolumn{3}{|c|}{${ }^{\mathrm{a}} \mathbf{B}_{2}$} & \multicolumn{3}{|c|}{${ }^{\mathrm{b}} \mathbf{B}_{6}$} & \multicolumn{3}{|c|}{${ }^{\mathrm{c}} \mathbf{B}_{12}$} & \multicolumn{3}{|c|}{${ }^{\mathrm{d}}$ Folic Acid } \\
\hline $\begin{array}{c}\text { Amount } \\
\text { Added } \\
\text { mg g }^{-1}\end{array}$ & $\begin{array}{l}\text { Amount } \\
\text { Found } \\
\text { mg g }^{-1}\end{array}$ & $\begin{array}{c}\text { Recovery } \\
\%\end{array}$ & $\begin{array}{l}\text { Amount } \\
\text { Added } \\
\text { mg g }^{-1}\end{array}$ & $\begin{array}{l}\text { Amount } \\
\text { Found } \\
\text { mg g }^{-1}\end{array}$ & $\begin{array}{c}\text { Recovery } \\
\%\end{array}$ & $\begin{array}{c}\text { Amount } \\
\text { Added } \\
\text { mg g }^{-1}\end{array}$ & $\begin{array}{l}\text { Amount } \\
\text { Found } \\
\text { mg g }^{-1}\end{array}$ & $\begin{array}{c}\text { Recovery } \\
\%\end{array}$ & $\begin{array}{l}\text { Amount } \\
\text { Added } \\
\text { mg g }^{-1}\end{array}$ & $\begin{array}{l}\text { Amount } \\
\text { Found } \\
\text { mg g }^{-1}\end{array}$ & $\begin{array}{c}\text { Recovery } \\
\%\end{array}$ \\
\hline 5.0265 & 5.0184 & 99.84 & 5.0418 & 5.0327 & 99.82 & 5.1347 & 5.1302 & 99.91 & 5.1385 & 5.0652 & 98.57 \\
\hline 10.0147 & 10.0113 & 99.97 & 10.1357 & 10.1462 & 100.10 & 8.0364 & 8.0154 & 99.74 & 9.5417 & 9.5524 & 100.11 \\
\hline 13.5461 & 13.5326 & 99.90 & 15.2481 & 15.2346 & 99.91 & 10.2207 & 10.2115 & 99.91 & 10.0132 & 10.0087 & 99.96 \\
\hline 15.1135 & 15.0478 & 99.57 & 20.3108 & 20.3216 & 100.05 & 15.1184 & 15.1063 & 99.92 & 15.1167 & 15.0314 & 99.44 \\
\hline 20.0028 & 20.0417 & 100.19 & 23.5107 & 23.5016 & 99.96 & 18.5174 & 18.5416 & 100.13 & 18.2145 & 18.2257 & 100.06 \\
\hline 25.2314 & 25.3153 & 100.33 & 25.0159 & 25.1327 & 100.47 & 20.2168 & 20.2511 & 100.17 & 20.1548 & 20.1734 & 100.09 \\
\hline $\begin{array}{l}\text { Mean }=99.9 \\
\text { Mean }=100 . \\
\text { Mean }=99.9 \\
\text { Mean }=99.7\end{array}$ & $\begin{array}{l}\text { andard dev } \\
\text { standard de } \\
\text { andard dev } \\
\text { andard dev }\end{array}$ & $\begin{array}{l}\text { tion } \\
\text { ation } \\
\text { tion } \\
\text { tion }\end{array}$ & $\begin{array}{l} \pm 0.268 ; \% \\
\pm 0.228 ; \% \\
\pm 0.16 ; \% \\
\pm 0.61 ; \%\end{array}$ & $\begin{array}{l}\mathrm{RSD}= \pm 0 \\
\mathrm{RSD}= \pm 0 \\
\mathrm{SD}= \pm 0 \\
\mathrm{SD}= \pm 0 .\end{array}$ & & & & & & & \\
\hline
\end{tabular}

The dependence of retention time on flow rate has been observed for both standard and sample and it was found that a increase in flow rate decrease the retention time of $B_{2}, B_{6}$, $\mathrm{B}_{12}$ and folic acid in a regular manner. The HPLC method has been found to be time saving with a high degree of precision and accuracy.

Table 2. Precision Under Repeatability Conditions $(n=6)$

\begin{tabular}{|c|c|c|c|c|}
\hline Determination & $\begin{array}{c}\text { Riboflavin } \\
\text { (\% L.S) }\end{array}$ & $\begin{array}{c}\text { Pyridoxine } \\
\text { (\%L.S) }\end{array}$ & $\begin{array}{c}\text { Cyanocobalamine } \\
\text { (\% L.S) }\end{array}$ & $\begin{array}{c}\text { Folic } \\
\text { Acid } \\
\text { (\% L.S) }\end{array}$ \\
\hline \hline 01 & 98.24 & 99.46 & 97.57 & 100.24 \\
02 & 98.76 & 99.35 & 97.87 & 100.51 \\
03 & 98.57 & 98.98 & 97.48 & 99.85 \\
04 & 99.01 & 99.32 & 98.09 & 99.89 \\
05 & 99.56 & 98.84 & 98.04 & 99.25 \\
06 & 99.36 & 99.02 & 98.24 & 100.15 \\
\hline Mean & 98.75 & 99.16 & 97.90 & 99.98 \\
\hline SD & \pm 0.48 & \pm 0.22 & \pm 0.31 & \pm 0.46 \\
\hline \% RSD & \pm 0.49 & \pm 0.22 & \pm 0.32 & \pm 0.46 \\
\hline
\end{tabular}

Table 3. Intermediate Precision $(n=4)$

\begin{tabular}{|c|c|c|c|c|c|}
\hline Instrument & Analyst & $\begin{array}{c}B_{2} \\
(\% \text { L.S })\end{array}$ & $\begin{array}{c}B_{6} \\
(\% \text { L.S })\end{array}$ & $\begin{array}{c}B_{12} \\
\text { (\% L.S })\end{array}$ & $\begin{array}{c}\text { Folic } \\
\text { Acid } \\
(\% \text { L.S })\end{array}$ \\
\hline \multirow{2}{*}{1} & A & 99.01 & 99.32 & 97.49 & 100.15 \\
\hline & B & 98.79 & 98.89 & 98.09 & 99.25 \\
\hline \multirow{2}{*}{2} & A & 98.81 & 99.01 & 98.11 & 100.74 \\
\hline & B & 99.59 & 98.30 & 98.54 & 100.04 \\
\hline Mean & & 99.05 & 98.88 & 98.06 & 100.05 \\
\hline SD & & \pm 0.373 & \pm 0.427 & \pm 0.432 & \pm 0.612 \\
\hline$\%$ RSD & & \pm 0.377 & \pm 0.432 & \pm 0.441 & \pm 0.612 \\
\hline
\end{tabular}

Table 4. Stability Indicating Results and Instrument Repeatability $(n=4)$

\begin{tabular}{|c|c|c|c|c|}
\hline \multirow{2}{*}{$\begin{array}{c}\text { Time Period } \\
\text { (Hour) }\end{array}$} & \multicolumn{5}{|c|}{ Peak Area of Standard Solution (a. u) } \\
\cline { 2 - 5 } & $\mathbf{B}_{\mathbf{2}}$ & $\mathbf{B}_{\mathbf{6}}$ & $\mathbf{B}_{\mathbf{1 2}}$ & Folic Acid \\
\hline \hline 0 & 7515091 & 3151394 & 7028085 & 9831283 \\
\hline 8 & 7501432 & 3152461 & 7014893 & 9824361 \\
\hline 16 & 7500981 & 3150873 & 7019476 & 9826147 \\
\hline 24 & 7501076 & 3145524 & 7011875 & 9819875 \\
\hline \multirow{2}{*}{$\begin{array}{c}\text { Time Period } \\
\text { (Hour) }\end{array}$} & & \multicolumn{4}{|c|}{ Peak Area of Sample (a. u) } \\
\cline { 2 - 5 } & $\mathbf{B}_{\mathbf{2}}$ & B $_{\mathbf{6}}$ & B $_{12}$ & Folic Acid \\
\hline \hline 0 & 353222 & 107092 & 813628 & 298368 \\
\hline 8 & 350146 & 109241 & 821476 & 297475 \\
\hline 16 & 351485 & 119976 & 814385 & 289956 \\
\hline 24 & 352673 & 118795 & 812469 & 287973 \\
\hline
\end{tabular}

\section{CONCLUSIONS}

This paper describes a simple, rapid, economic and accurate quantitative simultaneous estimation of water soluble vitamins, riboflavin, pyridoxine, cyanocobalamin and folic acid in neutraceutical products by HPLC. A validation of this method was carried out and showed that specificity, robustness and precision are guaranteed.

\section{REFERENCES}

[1] Hui, YH. Encyclopedia of Food Science and Technology, Vol. 4 (Q-Z). Wiley Interscience Publication: New York, 1991.

[2] Helrich, K. Official Methods of Analysis of the Association of Official Analytical Chemicals, $13^{\text {th }}$ ed.; Association of the Official Analytical Chemists, Arlington Inc: VA, 1990, pp. 65:970, 15:981.

[3] Helrich, K. Official Methods of Analysis of the Association of Official Analytical Chemicals, $13^{\text {th }}$ ed.; Association of the Official Analytical Chemists, Arlington Inc: VA, 1990, Vol. 33, p. 940.

[4] Brubacher, G.; Müller-Mulot, W. Vitamin B (Riboflavin) in Foodstuffs: HPLC Method, in Methods for the determination of Vitamins in Food-Recommended by COST 91, Elsevier Applied Science: New York, 1985. 
[5] Polansky, M.M.; Klein, B.P.; Becker, D.A.; Venugopal, P.B. Methods of Vitamin Assay, $4^{\text {th }}$ ed.; Association of Vitamin Chemists, Chapter 17, Wiley: New York, 1985.

[6] Gregory, III J.F. Methods for Determinations of Vitamins $B_{6}$ in Foods and other Biological Materials: A Critical Review. J. Food Compst. Anal., 1988, 1, 105-123.

[7] Vanderslice, J.T.; De Leenheer, A.P.; Lambert, W.E. Eds.; Modern Chromatographic Analysis of the Vitamins, Chapter 10, Marcel Dekker: New York, 1985.

[8] Food and Nutrition Board, National Research Council, Food Chemicals Codex, $3^{\text {rd }}$ ed.; National Academy Press: Washington DC, 1981, p. 363.

[9] The United States Pharmacopeia XXII (USP XXII-NF XVII), United States Pharmacopeial Convention, Inc Rockville: MD, 1990, p.343.

[10] Chin, H. B, Methods of Vitamin Assay, $4^{\text {th }}$ ed.; Chapter 19, Wiley: New York, 1985

[11] Rosenthal, H.L.; Harris, R.S. The Vitamins, $2^{\text {nd }}$ ed.; Academic Press, New York, 1968, Vol. II, p. 145.

[12] a) Skeggs, H. R.; The Vitamins, $2^{\text {nd }}$ ed.; Vol. VII, Academic Press, New York, 1968, p. 277. b) Baker, H.; Frank, O. The Vitamins, $2^{\text {nd }}$ ed.; Academic Press: New York, 1968, Vol. VII, p. 293.

[13] Hudson, T.S.; Subramanian, S.; Allen, R.J. Determination of pantothenic acid, biotin and vitamin $\mathrm{B}_{12}$ in nutritional products. $J$. Assoc. Off. Anal. Chemists, 1984, 67, 994-698.

[14] a) Herbert, V.; Bertino, J.R. Folic acid, György P, Pearson W-N The Vitamins, $21^{\text {st }}$ ed.; Academic Press: New York, 1967, Vol. VII, p. 243. b) Baker, H.; Frank, O. A Microbiological Assay for Folate Activity, 1967, ibid, p. 269.

[15] a) Keagy, P.M. Folacin-Microbiological and Animal Assays, $4^{\text {th }}$ ed.; 1985, pp 445. b) Augustin, J.; Klein B.P.; Becker, D.A.; Venugopal, P. B, Methods of Vitamin Assay, $4^{\text {th }}$ ed.; Wiley, New York, 1985, p. 445. c) Gregory III J.F. Folacin,-Chromatographic and Radiometric Assays, 1985, ibid, p. 473.

[16] a) Mc Cormack, J.J.; Newman, R.A. Chromatographic Studies of Folic Acid and Related Compounds, Marcel Dekker: New York, 1985. b) De Leenheer, A.P.; Lambert, W.E.; De Ruyter, M.G.M.; Eds.; Modern Chromatographic Analysis of the Vitamins, Marcel Dekker: New York, 1985.

[17] Brubacher, G.; Muller, M.W.; Southgate D.A.T. Folacin in Foodstuffs, in Methods for the Determination of Vitamin in FoodRecommended by COST 91, Elsevier Applied Science, New York, 1985, p. 158.

[18] Yanling, G.; Fei, G.; Sumangala, G.; Andrew, C.; Qinghai, S.; Mingruo, G. Quantification of water-soluble vitamins in milkbased infant formulae using biosensor-based assays. Food Chem., 2008, 110, 769-76

[19] Soledad, A-H.; Veciana-Nogue's, T.M.; Izquierdo-Pulido, M. Font, A. M. Determination of water-soluble vitamins in infant milk by high-performance liquid chromatography. J. Chromatogr., 1997, 778, 247-53.

[20] Rada, A.; Jasmina, B.S.; Olivera, A.C.; Sote, M. V. RP-HPLC determination of vitamins, folic acid and $\mathrm{B}_{12}$ in multivitamin tablets. J. Serb. Chem. Soc., 2005, 70, 1229-35 and references quoted there in.

(C) Perveen et al.; Licensee Bentham Open.

This is an open access article licensed under the terms of the Creative Commons Attribution Non-Commercial License (http://creativecommons.org/licenses/by$\mathrm{nc} / 3.0 /$ ) which permits unrestricted, non-commercial use, distribution and reproduction in any medium, provided the work is properly cited. 